\title{
A FIGURA DO “DECRETO" NO DIREITO BRASILEIRO E SEUS PRINCIPAIS PROBLEMAS: UMA BREVE ANÁLISE A PARTIR DE CASOS CONCRETOS
}

\author{
Janriê Rodrigues Reck \\ Caroline Müller ${ }^{2}$
}

\section{RESUMO}

Este trabalho busca compreender a figura jurídica do "decreto regulamentar". Dentre as várias questões a serem respondidas, as principais envolvem o decreto como aplicação da lei, e as dificuldades que emergem desta aplicação - feita sem a premissa primeira da interpretação jurídica ordinária: a existência de um "caso" ou "fatos". Para se compreender estes problemas, primeiramente a abordagem dogmática será analisada. Após, alguns casos paradigmáticos resolvidos pela jurisprudência.

Palavras-Chave: Decreto. Jurisprudência. Teoria do Direito. Significados jurídicos.

\section{INTRODUÇÃO}

A pergunta sobre o significado do decreto está na ponta da língua de qualquer operador jurídico, de estudantes de direito e mesmo de cidadãos mais bem informados: trata-se de um ato do poder executivo que regulamenta uma lei. Regulamentar a lei significa que o conteúdo do decreto versará sobre as minúcias que não cabe à lei detalhar, no sentido de melhor aplicação desta. Pressionando-se o interlocutor virtual mais além levará à falta de respostas, posto que este conhecimento superficial do senso comum nem de longe responde perguntas como "qual a situação hermenêutica do criador do decreto?"; "decreto é uma "aplicação" da lei?", "é possível dizer que o Decreto $n^{\circ} \mathrm{X}$ regulamentou "mal" a Lei $\mathrm{n}^{\circ} \mathrm{Y}$ ?"

São justamente estas perguntas - que ao ver do autor do trabalho restam irrefletidas pela maior parte da doutrina dogmática - que justificam o interesse em trabalhar este tema. É possível justificar socialmente o objeto do trabalho tendo em vista, além da cotidianidade com que decretos são produzidos, regulamentando leis, que esta atividade repercute, em muito, na vida do cidadão, posto que é no decreto que estarão condições para o exercício de direitos ou imposição de deveres. A ciência jurídica não responde aos reclames da cidadania, posto que não oferece, como meios de controle cidadão, nada mais do que poucas considerações, usualmente repetitivas e inúteis. No aspecto pessoal, a temática oferece grande interesse, por várias razões, dentre as quais encontram-se a possibilidade de melhor compreensão do fenômeno jurídico, e o apontamento das insuficiências e possibilidades das grandes teorias de interpretação do direito que se apresentam contemporaneamente.

Vários são os problemas a que este trabalho se direciona a resolver, quais sejam: 1) qual a leitura que a dogmática brasileira faz do decreto, e quais são suas 
características principais, bem como sua função, conforme esta mesma dogmática?; 2) é possível delinear, a partir de casos polêmicos, como os tribunais significam o decreto?; 3) é possível dizer que os tribunais superiores abordam adequadamente o instituto?

\section{INTRODUÇÃO AO DECRETO}

Este breve estudo tem por objetivo observar a tradição dogmática na conceituação e definição das questões fundamentais que envolvem o decreto. É fundamental observar como a dogmática trabalha o decreto, posto que é a ciência jurídica uma das estruturas que selecionam novos elementos ao direito e formam a sua tradição - tradição esta que, por sua vez, vai vincular o intérprete na aplicação da norma.

O decreto envolve uma alta complexidade de questões possíveis de serem trabalhadas. Este trabalho, de todo modo, vai se focar na atividade mesma de regulamentação como interpretação da lei. Mas alguns tópicos são fundamentais, e devem ser abordados, mesmo que rapidamente.

A principal questão é: que problema o decreto visa resolver, ou seja, qual a sua função? Esta pergunta não pode ser respondida a partir de alguma lógica, senão a da evolução do próprio Direito e da política. De fato, como não poderia deixar de ser, o decreto não é, de longe, uma exigência lógica, mas sim fruto de uma evolução histórica visando responder certos problemas. 0 Direito responde prontamente: 'Regulamento é a norma jurídica de caráter geral, editada pela autoridade administrativa, em matéria de sua competência, conferida pela lei formal, com o objetivo de facilitar-Ihe a aplicação,"3.

Em uníssono, a doutrina e a jurisprudência respondem que a função primária ${ }^{4}$ do decreto é regulamentar a lei. Esta resposta foi fácil. Mas, adiantando o debate com Gadamer, mais adiante colocado, qual é a pergunta que o decreto vem responder?

A evolução particular das instituições governamentais, do poder político, da opinião pública, do pensamento político-filosófico e do Direito legaram a idéia de que, em vista das arbitrariedades cometidas pelos reis absolutos, o poder deveria ser domesticado e posto, para publicidade e estabilidade, na linguagem do Direito. Isto é somado com o desejo de autonomia, ou seja, de procurar mecanismos para que o sujeito possa dar-se a lei. Este quadrado autonomia - direito - estabilidade legitimidade é o alter ego do trilema heteronomia - arbitrariedade - insegurança força. São precisamente aqueles valores que a Revolução Americana e Francesa, diante de reclames históricos muito mais antigos, visam estipular. Fazem-no mediante lógicas organizacionais que, ao mesmo tempo que inspiradas em experiências governamentais aqui e ali existentes, são muito mais fruto de reflexões teóricas de época. Põe-se, assim, a divisão de poderes.

É o Poder Legislativo a organização-tipo voltada à produção de direitos e obrigações públicas e privadas. É no Poder Legislativo que os cidadãos exercem sua autonomia de autoconvencimento, transformando programas políticos de vinculação da sociedade na linguagem do Direito e, procurando, com isto, dar-lhes 
uma estabilidade momentânea, até serem substituídos por outro programa. 0 Poder Executivo é locus de execução da lei e, como tal, deriva sua legitimação das leis estas sim legítimas porque fruto da autonomia do cidadão. Daí a razão pela qual não se legitima a atividade do Executivo, apenas a pessoa de seu comandante. A legitimação das atividades do Executivo é, deste modo, indireta:

[...] opostamente às leis, os regulamentos são elaborados em gabinetes
fechados, sem publicidade alguma, libertos de qualquer fiscalização ou
controle da sociedade ou mesmo dos segmentos sociais interessados na
matéria. Sua produção se faz apenas em função da vontade, isto é, da
diretriz estabelecida por uma pessoa, o Chefe do Poder Executivo, sendo
composto por um ou poucos auxiliares diretos seus ou de seus imediatos.
Não necessita passar, portanto, nem pelo embate de tendências políticas e
ideológicas diferentes, nem mesmo pelo crivo técnico de uma pluralidade de
pessoas instrumentadas por formação ou preparo profissional variado ou
comprometido com orientações técnicas ou científicos discrepantes.
Sobremais, irrompe da noite para o dia, e assim também pode ser alterado
ou suprimido 5 .

De fato, como será visto mais adiante, a dogmática está correta. Não é possível comparar-se a legitimação alcançada pelos processos de formação da lei e do decreto, por mais defeituoso que seja o primeiro e virtuoso que seja o segundo: o déficit de legitimidade é insuportável. Daí que a idéia, aferrada, com razão, na dogmática, de que o regulamento deve ater-se à lei. A idéia de que a autonomia se expressa em leis do legislativo, e que determinadas conquistas evolutivas, nesta linha, devam ser preservadas, fundamentam também conceitos fundamentais, quais sejam, o de Princípio da Legalidade e Estado Democrático. Ambos são conquistas evolutivas que se tornaram estruturas e programas fundamentais do Direito, quase que se tornando símbolos deste.

É que os dispositivos constitucionais caracterizadores do princípio da legalidade no Brasil impõem ao regulamento o caráter que se lhe assinou, qual seja, o de ato estritamente subordinado, isto é, meramente subalterno $e$, ademais, dependente de lei. [...] Daí que, em nosso sistema, de direito, a função do regulamento é muito modesta ${ }^{6}$.

Mais, a idéia de que o Executivo apenas pode regulamentar a lei reside na conquista evolutiva, plenamente fundamentável, do Estado Democrático de Direito:

Os regulamentos exprimem o exercício de uma competência normativa da Administração. Uma pura transferência da competência normativa genérica (mesmo infra legem) para o executivo contrasta com o princípio democrático e com o princípio do Estado de Direito. É isso que explica o facto de, na actualidade, não se conceberem regulamentos independentes que, pelo menos, não tenham fundamento legal no que respeita à matéria a regular"?

Até aqui, pode-se concluir, rasteiramente, que faz parte da compreensão do atual Estado Democrático de Direito a idéia de que a criação da norma é um, ou pelo menos, uma tentativa, de um exercício da autonomia. Mal ou bem, isto é feito dentro do âmbito onde debates são levados a efeito, o Poder Legislativo. Não pode o Poder Executivo criar leis, posto que não é o foro competente - afinal, dentro do Poder Executivo, pelo menos dentro da atual organização, não há debates plurais no que toca à elaboração do decreto. 
Não é necessário muito dissertar acerca das dificuldades de se criar normas suficientemente "precisas" no Poder Legislativo. Além de uma empreitada impossível, a vagueza normativa é parte do jogo político. Além disto, estratégia para prolongar a vida das normas. Somam-se estes fatores com a necessidade de ação por parte dos poderes públicos e a consagração da legalidade "genérica", além de um progressivo incremento da atividade administrativa, e tem-se como resultado um amplo espaço aberto para a "regulamentação". Trata-se de uma necessidade histórica e funcional: pelo menos dentro do Direito Administrativo, é praticamente impossível concretizar políticas públicas e demais programas sem os procedimentos $^{9}$ de sua materialização:

Regulamentação - Trata-se do poder de regulamentar (power of ordinance do direito constitucional inglês); no Brasil, tal poder dissimula, por vezes, a delegação legislativa, vedada pelo art.36, $\S 2^{\circ}$. A Constituição francesa do ano VIII, art. 44, estatuiu que o governo proporia as leis e faria os regulamentos necessários para lhes assegurar a execução. Nela foi que se inspirou, nesse ponto, a Constituição imperial do Brasil. A Constituição da República Argentina (art. 86, $\S 2^{\circ}$ ) ao tratar do assunto, recomendara ao Presidente da república ter o cuidado de "não alterar o espírito" das leis regulamentadas "com exceções regulamentares"10.

Aos poucos, a diferenciação entre poderes torna-se tal, e a atividade de regulamentação, tão consagrada, que a atividade regulamentar configura-se como uma "prerrogativa" do Poder Executivo, inviável de ser atacada pelos outros poderes.

A crescente complexidade da atuação dos poderes governamentais torna transparente uma visível maior quantidade de atos do Poder Executivo, atos de cunho "geral", e não "material".

\footnotetext{
Insere-se, portanto, o poder regulamentar como uma das formas pelas quais se expressa a função normativa do Poder Executivo. Pode ser definido como o que cabe ao Chefe do Poder Executivo da União, dos Estados e dos Municípios, de editar normas complementares à lei, para sua fiel execução ${ }^{11}$.
}

Talvez seja temerário afirmar que houve uma tendência, ou que esta tendência se mantém, de transferência da atividade de legislar do Poder Legislativo ao Executivo. É visível que na maior parte dos países, senão na totalidade, há incremento tanto na produção de "leis" quanto de "regulamentos", pelo menos do século XIX em diante. De todo modo, é verdade que há uma maior produção normativa executiva e uma crescente realocação das tensões jurídicas em direção ao Poder Executivo, no que talvez adquira alguma proeminência. É curioso, posto que a autocompreensão do Estado Democrático de Direito imputa ao Poder Executivo a tarefa de executar materialmente as normas. Isto não é tão simples, contudo. Daí a existência da atividade de regulamentação e sua incorporação na tradição dogmática, como essencial a regular atividade jurídica ${ }^{12}$.

Tanto é assim que o Decreto é prontamente posto no sistema piramidal, adquirindo validade da norma superior. ${ }^{13}$

A atividade regulamentar, deste modo, é posta junto a uma atividade legislativa latu sensu do Poder Executivo, e é justificada no sistema de freios e contrapesos. 0 
Poder Executivo assume a tarefa de editar normas gerais. Pode fazê-lo tanto originariamente (o que a tradição dogmática chama de 'regulamentos autônomos') quanto de maneira derivada, regulamentar. O Poder Executivo opera, portanto, em uma lógica semelhante à do Poder Legislativo, isto é, em um nível de racionalidade prática kantiana, perguntando-se acerca da conduta acertada, a despeito dos fatos. No regulamento, o Poder Executivo não faz nada imediatamente; põe, de outra banda, programas que serão seguidos. O Poder Executivo não age motivado também por um "caso" específico: os fatos relevantes são a edição de uma lei, seu dever normativo de regulamentar e os fatos que motivaram a referida a lei a regulamentar.

\begin{abstract}
Materialmente, o regulamento se assemelha à lei, pois, como ela, está voltado a uma série indeterminada de situações ou pessoas. Dela, entretanto, se afasta pelo regime jurídico que o rege, já que, como repetidas vezes acentuaremos, está hierarquicamente submetido à lei ${ }^{14}$.
\end{abstract}

Todas as perplexidades que envolvem o Poder Legislativo (como é possível leis "gerais'?) acorrem também ao Poder Executivo. Não se pode, idealisticamente, fechar os olhos para a realidade: a despeito das dificuldades, o Poder Executivo entende a lei, regulamenta-a, os servidores compreendem a lei e o decreto, e agem conforme estes. Fechar os olhos a esta realidade é fechar-se em um mundo que se pretende crítico, mas que na realidade é meramente uma manifestação de chauvinismo intelectual, tantas vezes inspirador de um ceticismo artificial, noves fora o seu terrível ônus de prova: teriam de provar que as pessoas "imaginam" que compreendem o decreto e a lei.

A atividade legislativa ${ }^{15}$ do Executivo, no Brasil, manifesta-se através de Medidas Provisórias, Leis Delegadas e Decretos Regulamentares. ${ }^{16}$ Os dois primeiros veículos estão inseridos dentro da Constituição como espécies legislativas, e, salvo restrições constitucionais, podem criar direitos e obrigações livremente. Para os fins deste trabalho, contudo, esta temática não interessa. Interessa, isto sim, a figura "decreto".

O decreto é um tipo de ato, formal, advindo do Poder Executivo ${ }^{17}$. Geralmente é observado mais da perspectiva do Direito Administrativo que do Direito Constitucional. Assim, os juristas, se instados a responder qual a "natureza jurídica" do decreto, provavelmente a maior parte responderá que se trata de um ato administrativo, e não de uma espécie legislativa.

Os decretos podem ser "gerais" ou "particulares" (materiais). No caso do decreto particular, assume uma forma do tipo "Nomeie-se Maria para o Conselho tal" ou "Exonere-se José". Trata-se aqui meramente de manifestações do Poder hierárquico ou disciplinar da Administração Pública. Não é também este o tipo de decreto a preocupação do trabalho. Interessa a manifestação do Poder Normativo.

O fundamento de validade do decreto normativo, como não poderia deixar de ser, encontra estribo constitucional:

Art. 84. Compete privativamente ao Presidente da República:

IV - sancionar, promulgar e fazer publicar as leis, bem como expedir decretos e regulamentos para sua fiel execução;

a) organização e funcionamento da administração federal, quando não 
implicar aumento de despesa nem criação ou extinção de órgãos públicos; (Incluída pela Emenda Constitucional $n^{\circ} 32$, de 2001)

b) extinção de funções ou cargos públicos, quando vagos; (Incluída pela Emenda Constitucional $n^{\circ} 32$, de 2001)

A tradição, no direito brasileiro, sempre fora a de que os decretos normativos só poderiam ser os decretos executivos, isto é, aqueles referidos na parte final do inciso IV do art. 84: "para sua fiel execução" [da lei]. A Emenda Constitucional no 32 , cuja intenção declarada fora desburocratizar a Administração Pública, reviveu os decretos autônomos, isto é, decretos que podem criar ou extinguir direitos (no caso, organização da Administração Pública, e extinção de funções e cargos públicos, quando vagos). Novamente, é importante ressaltar que não é este tipo de regulamento a preocupação do presente trabalho. Se bem que interessantes questões hermenêuticas possam daí emergir, o decreto executivo já apresenta complexidade bastante. Daqui por diante, decreto executivo e regulamento ${ }^{18}$ serão tomados como sinônimos.

Nesta toada, o Direito cria um problema que ele tem de responder. 0 decreto parece ser uma categoria fundamental para dar conta das demandas da política e da administração. Mas esta solução cria uma série de outros problemas. 0 principal deles é o da vinculação do decreto executivo à lei. Isto será deixado para mais adiante. Estas questões serão meramente exploratórias, para deixar clara a dimensão da problemática.

A primeira questão é: para quem o decreto é dirigido? A doutrina usualmente tem uma interpretação restritiva, apontando que o decreto volve-se à Administração Pública:

Os regulamentos contêm comandos dirigidos, não aos indivíduos, que só devem obediência à lei (art. 153, $\$ 2^{\circ}$ da CF), mas aos órgãos do Poder Executivo, subordinados hierarquicamente ao Chefe da Administração Pública. Não produzem, pois, efeitos junto aos particulares; endereçam-se, sim, aos funcionários executivos, que produzem as normas individuais ${ }^{19}$.

Não tão simples. Os decretos apontam, em geral, sim, à Administração Pública. Isto é bem verdade em ramos do direito tais como o Direito Previdenciário, Tributário e Administrativo. Mas o decreto também estabelece a forma como direitos e obrigações, além da explicitação de significados, advindos da legislação previdenciária, tributária e administrativa serão exercidos pelos particulares; neste sentido, não há dúvidas que os decretos, mesmo nestes ramos, estabelecem comportamentos para os particulares. Mas a realidade é ainda maior: vê-se decretos regulamentando o Estatuto da Terra, a Lei de Duplicatas, cheques, microempresa, juizados especiais, descanso semanal remunerado, aprendizes, etc., enfim, parece não haver ramo do Direito que escape à atividade regulamentar do Poder Executivo, a despeito da opinião doutrinária.

Esta pergunta acima se liga à pergunta de se o decreto cabe em qualquer ramo do direito. Novamente a resposta é a mesma: a doutrina vincula o decreto às atividades administrativas; na prática, há uma plêiade de decretos regulamentando as mais diversas atividades, como citado. Um ingrediente que aumenta a dificuldade é o de que uma série destes decretos foram elaborados nas ordens constitucionais anteriores. Persiste a dúvida se a ordem constitucional inaugurada em 1988 
recepcionaria decretos regulamentando direitos trabalhistas, por exemplo. De todo modo, não é fácil alcançar, a primeira vista, uma solução constitucional, posto que a norma constitucional aponta que o decreto regulará leis, sem dizer quais tipos de leis.

A doutrina vacila em dizer se existe ou não um dever de regulamentar. Se, de um lado, o Poder Executivo é independente, de outro, ele não pode ter o poder de deixar ineficaz uma dada norma, pois aí seria invadir as atribuições do Poder Legislativo. Interessante é o lado contrário deste debate: quais os limites de autonomia da própria Administração, isto é, até onde ela pode resistir à legislação? Este debate liga-se aos limites da divisão de poderes, onde ao Legislativo é vedado criar leis individuais e levar a efeito atos materiais, competências que são reservadas ao executivo. São decorrências destes limites o direito do Poder Executivo de autoorganizar-se, elaborando sua estrutura interna e planejamento governamental. Exemplo disto são as reservas de iniciativa de lei ao Poder Executivo presentes na Constituição. Mas casos há onde a Lei não interfere com a estrutura do Poder Executivo, sendo saliente que a falta de um decreto regulamentar prejudica a própria lei.

Na mesma linha de perguntas que remontam à divisão de poderes, é possível perguntar-se: pode o legislador proibir a regulamentação de uma lei? Pode o legislador estipular prazo para a regulamentação? Provavelmente o Direito encontrará resposta, mas terá de resignificar os textos que tratam da divisão de poderes. A pretensão deste trabalho é mais modesta e visa, finalmente, ao problema da vinculação do decreto à lei.

De fato, apontou-se que, corretamente, a dogmática afirma que o decreto deve apenas "regulamentar" a lei. Trata-se do maior problema. A doutrina, à falta de instrumentos mais sofisticados, defende limites para o poder regulamentar com 0 que dispõe, ou seja, categorias clássicas de obrigações e direitos. As dificuldades são compreensíveis, posto que as categorias metafísicas de subsunção e chauvinismo jurídico são levados ao extremo no Decreto, daí a razão de um silencio eloqüente em problematizar a vinculação lei-decreto. A leitura mais crítica resume-se a protestos pelo fato de não ter o decreto seguido a lei.

Uma das questões importantes que se pretende ver enfrentada é o da necessidade de regulamentação. Existe algum tipo de lei, pelo modo de sua apresentação, que necessita ser regulamentada, e outro tipo, que não? A doutrina responde que sim, há diferentes graus de densidade da norma.

Roque Carrazza, por exemplo, pensa que apenas leis não auto-aplicáveis merecem regulamento: "podemos, pois, dizer que, no Brasil, o regulamento é um ato normativo, unilateral, inerente a função administrativa, que, especificando os mandamentos de uma lei não auto-aplicável, cria normas jurídicas gerais' ${ }^{20}$. Leis auto-aplicáveis seriam aquelas que não necessitam de maiores explicações, como o Código Civil e as leis penais. Também é a opinião de Celso Antônio Bandeira de Mello. 
exaustivamente, isto é, com todas as minúcias, a forma exata da atuação administrativa pressuposta" ${ }^{21}$.

Daí porque a maioria dos doutrinadores preferir dizer que o decreto é apontado para o Administrador público, e não para o público em geral. Afinal, é o Administrador público que deverá materializar a lei. Dificil para a doutrina admitir dois fenômenos conjuntos: a supremacia da lei e a possibilidade de o decreto obrigar particulares. Como se opera em um nível lógico de observação única, não é possível, para a doutrina, admitir a lei valer mais do que o decreto, e, ao mesmo tempo, o cidadão ser obrigado a ambos. Ou um, ou outro. Obviamente que tal descrição destoa da prática jurídica, motivo pelo qual é necessário encontrar observações mais complexas.

Interessante questão é a de que se é possível encontrar uma solução modalizada em sim/não para a questão de se a atividade regulamentar é discricionária. Significa refletir se o Poder Executivo pode regulamentar de qualquer maneira, ou há uma maneira ótima de regular, ou se depende, e em que casos.

Para Celso Antônio Bandeira de Mello, a atividade regulamentar é discricionária $^{22}$. Para o referido autor, onde não houver espaço para a atuação administrativa, descaberá decreto; do mesmo modo, quando toda a lei for vinculante. Para Celso Antônio, contudo, uma vez aberto o espaço para a densificação, o regulamento será discricionariamente criado.

Daí que o regulamento discricionariamente as procede e, assim, cerceia a liberdade de comportamentos dos órgãos e agentes administrativos para além dos cerceios da lei, impondo, destarte, padrões de conduta que correspondem aos critérios administrativo a serem obrigatoriamente observados na aplicação da lei aos casos particulares ${ }^{23}$.

Na opinião de Celso Antônio Bandeira de Mello, a atividade regulamentar, de outra banda, é necessária não por imperativos lingüísticos, mas por força de uniformização do trato para com o cidadão:

Sem estes padrões impostos na via administrativa, os órgãos e agentes administrativos guiar-se-iam por critérios díspares ao aplicarem a lei, do que resultariam tratamentos desuniformes aos administrados. A mesma lei seria executada de maneiras distintas ${ }^{24}$.

Parece, contudo, que não é tão simples assim a posição do administrativista. De fato, existem âmbitos de regulamentação perfeitamente legítimos e abertos, e que permitem que a Administração Pública exerça sua liberdade. Quando os fins são postos claramente, não há porque se limitar esta liberdade, pena de interferência entre os poderes.

Por exemplo, é irrelevante, na ótica do cidadão, se seu requerimento vai passar por tal funcionário, ou tiver o procedimento com " $n$ " passos; ao cidadão importa o efetivo conhecimento de seu conteúdo por alguém competente para decidir. Este parece ser o espaço legítimo para o decreto. Mas, novamente, outras complexidades se impõem. Isto porque os procedimentos sempre estão mesclados com conteúdos, e, sob determinada observação, são também eles mesmos conteúdos. Se uma lei estabelece, por exemplo, que o segurado deverá apresentar a "documentação 
necessária" para que faça jus a benefício previdenciário, na teoria dominante, o decreto poderá estabelecer quaisquer documentos que sejam, de modo a inviabilizar a concessão do referido benefício. Daí a necessidade de se estabelecer meios de controle da discricionariedade.

A própria doutrina, por outras vias, combate a discricionariedade na regulamentação:

Ao regulamentar uma lei tributária não auto-aplicável, o Executivo precisa interpretá-la. Em outros termos, a emissão do decreto, que veicula o regulamento, deve ser precedida, lógica e cronologicamente, de um labor exegético, ao qual não se pode furtar o Chefe da Administração Pública [...] Tal interpretação alberga dois momentos; a saber: 1) o da determinação exata da moldura que a lei tributária fixa, com todos os caminhos que, dentro dela, podem prosperar; e, 2) o da opção por um desses caminhos possíveis [...] Percebe-se, disto tudo, que a lei tributária ao ser regulamentada limita o poder discricionário de que, neste particular, está investido o Chefe do Executivo [...] $]^{, 25}$

Eros Roberto Grau tenta responder ao problema estabelecendo algumas distinções.

Ora, há visível distinção entre as seguintes situações: i) vinculação da Administração às definições da lei; ii) vinculação da Administração às definições decorrentes - isto é, fixadas em virtude dela - de lei. No primeiro caso estamos diante da reserva da leí, no segundo, em face da reserva da norma (norma que pode ser tanto legal quanto regulamentar, ou regimental) ${ }^{26}$.

Quando a lei expressamente define algum instituto, o decreto deve se ater aquele significado. Quando a lei é vaga e permite definições, outras normas, inclusive o decreto, poderão definir os termos. Algumas vezes, parece que a norma necessariamente remete ao decreto, para que ganhe concretude. Eros dá o exemplo da norma penal em branco das drogas ilícitas, cuja definição é posta em regulamento. Novamente, a questão se põe: qualquer coisa pode ser droga ilícita/lícita? É possível dizer que o Executivo "andou bem" ao alocar aquela droga como ilícita/lícita?

Pontes de Miranda dá uma solução completamente diferente: quando a lei é tão vaga que deixa dúvidas, o Executivo tem de encolher-se, posto que não é sua função fazer cessar qualquer tipo de dúvida: 'Onde a lei oferece dúvida, não é ao Poder Executivo que toca varrê-la, ${ }^{, 27}$. Para Pontes de Miranda ${ }^{28}$, o decreto tem mera função redundante-procedimental.

De todo modo, a doutrina é unânime no sentido de que o decreto executivo não pode ir além das obrigações geradas na norma legal ${ }^{29}$ :

Se a regra é impositiva, ou proibitiva, isto é, de direito cogente, ao regulamento não é dado torná-la regra dispositiva ou interpretativa [...] 0 regulamento é proposta de interpretação ou conjunto de normas de direito formal administrativo. Nenhum princípio novo, ou diferente, de direito material se lhe pode introduzir [...] Vale dentro da lei; fora da lei, a que se reporta, ou das outras lei, não vale ${ }^{30}$. 
Enfim, o ciclo inicial está completo. Dado o estado atual do Estado Democrático de Direito, entende-se que só a lei é produzida a partir da autonomia do sujeito. Regulamentar, contudo, é necessário. Esta regulamentação, todavia, não poderá ir além do que posto na lei, senão há, aí, um ataque ao próprio Estado Democrático de Direito e à liberdade, igualdade e justiça que visa proteger. Surge, então, finalmente, a difícil questão de se saber se o decreto regulamentou adequadamente uma norma legal. Antes, contudo, outra discussão, que também ajuda a jogar luzes sobre o problema.

A discussão que emerge dos defeitos do decreto é interessantíssima. Trata-se de perguntar em quais categorias de reciclagem normativa - existentes para a autopreservação do Direito - que se encaixam os defeitos do decreto, isto é, na ilegalidade ou na inconstitucionalidade. As dificuldades são várias, principalmente a começar pela divisão mesma, visto que qualquer ilegalidade é, no final das contas, uma inconstitucionalidade. $O$ ordenamento criou, para dar conta disto, a tese da inconstitucionalidade reflexa, que gera inúmeras dificuldades, mas é isto que se tem para trabalhar.

Algumas proposições iniciais mais fáceis, para então se alcançar maior dificuldade.

Como, pela topografia constitucional, o decreto não é espécie legislativa, mas ato administrativo, ele não está sujeito, em princípio, ao controle concentrado de constitucionalidade. Resta saber se, via difusa, isto é possível.

A proposição primeira é a mais fácil, mas também a mais difícil. Explica-se: se o decreto contraria a lei, há uma ilegalidade, e a inconstitucionalidade é apenas reflexa. Não caberão ações de controle concentrado, e tampouco jurisdição no STF; mas ações coletivas poderão dar conta do problema, além da solução individual. Uma ilegalidade pode ser fácil de vislumbrar: a lei diz "não incidirá tributo na saída da mercadoria" e o decreto diz "incidirá tributo na saída da mercadoria". Como diz Pontes, "os regulamentos têm de obedecer às leis, quer àquelas a que se referem, quer a outras que rejam a sua matéria. Regulamento que foge da lei regulamentada é regulamento ilegal',31

O problema se torna bem mais complicado se se retomar o exemplo anterior, de "documentação necessária". Em princípio, parece mero procedimento, mas é um procedimento que garante ou inviabiliza um direito. Novamente, deixa-se isto para mais adiante.

Se um decreto regulamenta lei que não existe, há, aí, inconstitucionalidade, posto que não há lei para contrastar. $O$ decreto invadiu a competência do poder legislativo. O curioso é que, neste caso, há aptidão para subida de recurso extraordinário, tendo em vista a ofensa à competência prevista em norma Constitucional. Se se interpretar de maneira ainda mais radical, o decreto sem lei sujeitar-se-á a controle concentrado, posto que o art. 102, a, da Constituição Federal, utiliza os termos "ato normativo federal".

Toda esta argumentação se aplica também à hipótese, desta vez mais sutil, de o decreto regulamentar "fora" ou "além" da norma constitucional. Por exemplo, a Lei 
pode estipular "1CMS de $12 \%$ para automóveis", e silenciar no que toca às bicicletas. Se o decreto normatizar que os "veículos" pagarão $12 \%$ há, neste caso, uma fuga da competência, e, neste sentido, o decreto será inconstitucional.

Se o regulamento cria direitos ou obrigações novas, estranhas à lei, ou faz reviverem direitos, deveres, pretensões, obrigações, ações ou exceções, que a lei apagou, é inconstitucional ${ }^{32}$.

Pontes tenta resumir o problema:

\begin{abstract}
Se o regulamento se afasta da lei, é inconstitucional. O Poder Judiciário pode dizê-lo, de acordo com os princípios do judicial control. [...] Se o regulamento interpretou a lei e se está a discutir se a sua interpretação foi, ou não, acertada, o que em verdade se discute é a sua legalidade. Se o Poder Judiciário adota outra interpretação, a que o regulamento deu tem de se considerar contrária à lei ${ }^{33}$.
\end{abstract}

O problema é que toda vez que um decreto regulamenta "mal" uma lei, por qualquer motivo que seja, o Poder Executivo ultrapassou seus limites. $O$ mais singelo engano de significado é uma invasão daquilo que pertence ao Legislativo. Se se pensar assim, inconstitucionalidade direta há sempre, e os decretos submeter-seiam, indiscriminadamente, ao controle difuso e concentrado de constitucionalidade.

Uma outra complexidade é adicionada à discussão. É intuitivo que, nos termos acima, o Judiciário tem poder para invalidar, pelos motivos constitucionais, os decretos. Agora, teria o Poder Legislativo tal poder? É claro que interessa ao Legislativo, enquanto organização, que as leis sejam bem interpretadas, em uma visão otimista das instituições. Isto significa que o Legislativo poder fazer este controle por si só. A Constituição Federal responde:Art. 49. É da competência exclusiva do Congresso Nacional: [...] V - sustar os atos normativos do Poder Executivo que exorbitem do poder regulamentar ou dos limites de delegação legislativa; [...].

Note-se que a Constituição, deste modo, autoriza ao Poder Legislativo que proceda ao controle da legalidade/constitucionalidade dos decretos. 0 Poder Legislativo utilizará do instrumento normativo idôneo às questões relativas à sua competência exclusiva, que é o Decreto Legislativo. Para tanto, os legisladores terão de interpretar se o decreto bem ou mal regulamentou uma lei, e é necessário instrumentos para tanto.

Forma-se uma tensão delicada entre um Executivo que tem um poder autônomo de regulamentar, e um Legislativo que tem instrumentos para fiscalizar e neutralizar este poder.

Isso vai fazer com que novamente o argumento da incompetência e invasão de poderes venha à tona, e, deste modo, haveria sempre ofensa direta à Constituição. Enfim, sempre que o Poder Legislativo sustar um ato do Poder Executivo, poderá estar sustando de maneira incorreta. Como é uma ofensa direta à Constituição, e não uma indireta, e se trata de um ato normativo, abrir-se-iam tanto as portas do Recurso Extraordinário quanto do controle concentrado. Note-se a complexidade das cadeias de observações/interpretações: o Executivo interpreta a lei, editando um decreto; operação que por sua vez será observada a partir do Legislativo, que 
deverá interpretar as duas normas com a edição de uma terceira (decreto legislativo) e, finalmente, a do Judiciário, que terá de fazer a leitura de tudo isto junto, além de, por óbvio, ter de realizar as outras operações inerentes à interpretação contemporânea, como levar em conta o paradigma do Estado Democrático de Direito, a supremacia da Constituição, etc.

Volva-se ao primeiro problema, qual seja, o da vinculação do decreto à lei. Pela compreensão ordinária do problema, não pode o decreto criar direitos e obrigações. Isto não pode ser levado muito a sério, posto que, assim fosse, não haveria decreto (se o decreto diz qual é a droga ilícita, gera o direito de perseguição e punir do Estado, e obrigação de não consumir a droga; se o decreto diz quais são os documentos necessários, gera ao cidadão a obrigação de trazê-los para efetivar seu direito ${ }^{34}$ ). Talvez fosse menos temerário dizer que não é possível criar direitos e obrigações que não sejam instrumentais aos direitos postos na lei. Mas isto gera uma série de outros problemas conceituais, que não serão analisados agora.

Para que o decreto "regulamente" a lei, é necessário compreendê-la. Eis aí a delicadeza da situação. Vai-se compreender normas gerais para criar normas gerais; trocar-se-ão universais por universais - se tais categorias ainda forem de algum uso. O fato é: 0 decreto não resolve caso concreto algum, até porque ele não existe. 0 decreto não tem, contudo, aquela liberdade significativa que a lei tem em face da Constituição ${ }^{35}$. Os fatos são os de conhecimento geral (usam-se drogas tais), científicos (drogas tais costumam provocar os danos $x$ no corpo humano) $e$ prospectivo (usualmente, os documentos " $n$ " são aptos a gerar a prova de tal situação); não há nenhum específico. A pergunta é se é um processo de dois estágios, ou um estágio, e em que sentidos isto pode ser dito.

A doutrina aponta para esta necessidade de interpretação:

Regulamentar é mais difícil do que fazer a própria lei; exige pleno conhecimento do alcance das regras jurídicas legais (o de que nem sempre tem noção clara os legisladores) e do ramo do direito em que a lei mergulha $^{36}$.

Compara-se a atividade regulamentar com a do intérprete doutrinário:

O poder que tem o regulamento não é mais, intrinsecamente, do que o do
intérprete doutrinário, e, às vezes é menos $[\ldots]^{37}$. [...] A interpretação que o
Executivo dá a uma lei tributária, ao regulamentá-la, é tão passível de
críticas como a que despede qualquer doutrinador, por maior que seja sua
idoneidade intelectual. A única interpretação que vincula a todos é a
realizada pelo Poder Judiciário, ${ }^{, 38}$.

Para a doutrina, deste modo, o feitor do decreto terá de interpretá-lo não como um juiz, mas sim como um intérprete doutrinário, sem a pressão do caso. Parece estranho, posto que é a mesma doutrina a dizer, com exceção de Pontes, que a Administração Pública tem discricionariedade para regulamentar. De todo modo, a intuição principal parece justa: a de que Executivo é um intérprete do texto. Nem poderia deixar de ser, visto ser irrespondível a pergunta de quando não há interpretação. De todo modo, com certeza, e a doutrina aponta isto com certa razão, muito embora com muita ingenuidade, os legisladores trabalhem com uma plêiade muito maior de textos possíveis e de convencimento recíprocos; o legislador 
responde a pergunta, enfim, da razão prática: "que devemos fazer?" Tudo indica que o material com o qual o Executivo está autorizado a trabalhar é muito menor, mas isto é uma hipótese a ser confirmada ou refutada mais adiante.

De todo modo, o regulamento possibilita os enlaces comunicativos, que outro modo seriam possíveis, mas caóticos. Reduz, assim, as possibilidades significativas possíveis, na missão constitucional de permitir a execução da lei mesma. "Regulamentar é editar normas que se limitem a adaptar a atividade humana ao texto, e não o texto à atividade humana, - cria meios que sirvam à atividade humana para melhor se entender o texto,39. O decreto é, enfim, um potencializador da comunicação entre lei e destinatário, e, conforme a autocompreensão do Estado Democrático de Direito, a isto deve se resumir.

Finalmente, Pontes chega a uma conclusão sábia, porém utópica, se levada às últimas conseqüências: "Quanto menos se regulamenta, melhor"40. No próximo capítulo, intenta-se trazer algumas discussões jurisprudenciais, para os fins de dar maior colorido a esta discussão.

\section{CASOS POLÊMICOS NA JURISPRUDÊNCIA BRASILEIRA}

Para Eros Roberto Grau, a tarefa de significação da Constituição foi conferida ao Supremo Tribunal Federal, de modo que:

O momento é propício para a afirmação de que, em verdade, a Constituição nada diz; ela diz o que esta Corte, seu último intérprete, diz que ela diz. E assim é porque as normas resultam da interpretação e o ordenamento, no seu valor histórico-concreto, é um conjunto de interpretações, isto é, conjunto de normas; o conjunto das disposições (textos, enunciados) é apenas ordenamento em potência, um conjunto de possibilidades de interpretação, um conjunto de normas potenciais ${ }^{41}$.

Este trabalho parte de premissas diferentes. A Constituição comunica algo. De todo modo, esta seção tem por intento investigar algumas contribuições que a jurisprudência traz para a o desenvolvimento do tema.

Na Ação Direta de Inconstitucionalidade $n^{\circ}$ 3.394-8, do Amazonas, relator Sr. Ministro Eros Grau questionava-se acerca da possibilidade de a Lei autorizar o Poder Executivo a regulamentar e, mais, a estipular prazo para que o regulamento seja criado, além de outras inconstitucionalidades. Parece que é completamente irracional a lei autorizar e determinar prazo para regulamentação, ao mesmo tempo.

De todo modo, no que toca à autorização para regulamentar, o STF considerou-a despicienda, de modo que completamente inútil sequer declarar tal termo inconstitucional, por inútil. No que toca ao prazo para regulamentação, o tribunal considerou-o inconstitucional, visto que invadia a independência do Poder Executivo. Este ponto interessa, não tanto por suas questões processuais, mas de conteúdo: o Executivo é livre, na visão do STF, pelo menos no que toca a necessidade de regulamentar e no tempo. Não há pressão de decisão, pelo menos jurídica, em face do Poder Executivo.

Na ADIN no 1435-8, Distrito Federal, Relator Sr. Ministro Francisco Rezek, a 
questão era saber se o decreto podia regulamentar algo antes da edição de lei, e se isto é uma inconstitucionalidade ou uma ilegalidade. Além disso, procurava-se saber se a edição de lei após o decreto convalida os vícios deste. Decidiu-se que a edição de lei não convalida $o$ decreto, e que se trata de uma inconstitucionalidade a existência de decreto regulamentando lei que ainda não existe. Tanto foi assim que se permitiu a utilização do controle concentrado, o que não seria possível, em outra situação, conforme já explicitado no capítulo anterior, mediante recurso à antiga doutrina. $O$ argumento do Supremo é simples, correto e singelo: decreto regulamenta, e regulamentar só se pode fazer com aquilo que já existe; se não há lei, o Poder Executivo estaria legislando, e isto é ofender a tripartição de poderes. Nesta ocasião, o Sr. Ministro ainda alegou, recorrendo à doutrina, que o decreto dirige-se à Administração Pública, e não aos demais cidadãos, muito embora isto não tenha sido objeto da discussão.

A ADIN 996-6, distrito federal, Relator Sr. Ministro Celso de Mello, discute esta mesma questão. A discussão era saber se o regulamento, quando extravasa os limites legais, ofende diretamente ou indiretamente a Constituição. Tratava-se de decreto federal que criava tipos administrativos, visando sancionar condutas que prejudicavam o consumidor. $O$ argumento do STF, reforçando jurisprudência já consolidada, analisa a questão apenas da perspectiva doutrinária, sem observar a partir da Constituição. A ofensa, na visão do STF, é à Lei; sendo apenas atingida a Constituição reflexamente. Não há maiores explicações sobre como saber quando algo ofende diretamente ou indiretamente a lei, de modo que não é possível construir critérios para discernir como o STF criou o critério de distinção direta/indireta. Parece ser algo que vem à tona intuitivamente e não precisa ser fundamentado. No mesmo julgamento, apontou para uma determinada discricionariedade na regulamentação.

No RE 343.446-2, Santa Catarina, Relator Sr. Ministro Carlos Velloso, a controvérsia residia na possibilidade de a Lei delegar ao Poder Executivo para que, via regulamento, densifique o significado de certas normas. Ocorre que a Lei 8.212 grava, tributariamente, de maneira mais rigorosa aquelas empresas cujo ambiente de trabalho apresente risco de acidente "leve", "médio" e "grave". Serão atribuídas às empresas tais qualificações quando sua "atividade preponderante" for, respectivamente, leve, média e grave. A lei, contudo, não estabelece parâmetros precisos (diz apenas que serão elaborados através de estatísticas) do que vem a ser aquelas graduações, e tampouco atividade preponderante. Delega isto ao decreto. A pergunta é saber se a lei pode fazer isto. Na ocasião, o tribunal considerou isto possível. Ocorre que aí não seria uma "delegação pura", mas sim a transferência ao Executivo de algo que, na visão do Tribunal, seria de inviável produção na esfera legislativa. Esta delegação "regulamentar" seria possível desde que a delegação seja revogável, seja razoável e se atenha aos parâmetros mínimos legais. 0 fundamento deste poder encontra-se em um princípio pragmático, de impossibilidade legislativa de normatizar precisamente, além do próprio âmbito legítimo de movimento do Poder Executivo dentro do esquema de divisão dos poderes.

Note-se, portanto, que a jurisprudência afasta-se da doutrina neste aspecto. Enquanto que a doutrina é irredutível no sentido de que o decreto nada pode criar, 0 Supremo considera isto possível, desde que dentro de uma "razoabilidade" e dentro dos standarts legais. A linguagem dos acórdãos é cuidadosa, contudo, utilizando o 
termo "complementar". Na terminologia do Supremo, o decreto pode ir um pouco além de 'regulamentar"; pode, também, "complementar"; "criar", nunca.

De todo modo, o Supremo evitou fazer um exame entre a regulamentação e a lei. Estipulou que é uma tarefa infraconstitucional e que, portanto, não poderia ser conhecida via recurso extraordinário.

O STJ segue no sentido da validade do decreto, isto é, que seria válido o decreto densificar a lei, mesmo que esta não traga parâmetros minimante precisos:

\begin{abstract}
Desde a edição da Lei 8.212/91 os enquadramentos das atividades nos graus de risco vêm sendo feitos através de lista anexa aos decretos regulamentares: Decretos 356/ 91, 612/ 92, 2.173/ 91 e Decreto 3.048/99. Doutrinariamente, há posições contrárias, sob 0 argumento da impossibilidade de o Legislativo delegar ao Executivo sem estabelecer critério legal, permitindo, desta forma, que a alíquota da contribuição ficasse sem o controle da legalidade. Ora, o princípio da legalidade tem por escopo garantir que a relação entre o Fisco e contribuintes se desenvolva sem surpresas, colocando estes últimos a salvo da discricionariedade do Executivo, e assegurando a criação e a majoração de tributos só se faça por ato do legislador, ressalvadas as hipóteses constitucionalmente excepcionadas. [...] 0 princípio esculpido na Lei Maior é repetido no CTN, art. 97, de sorte que ao regulamento o direito brasileiro reserva o papel de explicitar o conteúdo da lei, para sua execução, estabelecendo os meios e formas de cumprimento de suas disposições e, finalmente, fixando os critérios de interpretação e aplicação. [...] $\mathrm{E}$ isto porque, pela universalidade das diversas atividades empresariais, seria praticamente impossível dar o legislador o diapasão dos graus de risco, o que ficou a critério do Executivo [...] Pergunta-se então: como seria possível ao legislador descer aos detalhes para conceituar qual a atividade do risco leve, médio ou grave? 0 Decreto 2.173/97, posterior ao Dec. 612/92, mas a par dos já mencionados, não perdeu de vista a atividade preponderante da empresa, dentro de um critério de absoluta razoabilidade. Assim, em nível infraconstitucional, não vislumbro a ilegalidade apontada no especial interposto pela empresa ${ }^{42}$.
\end{abstract}

Questão interessantíssima fora julgada na Ação Direta de Inconstitucionalidade $n^{0}$ 1.553-2, Distrito Federal, relator Marco Aurélio. A Câmara Legislativa criou uma lei, que fora regulamentada pelo Executivo. A Câmara considerou que o decreto desbordou os limites, e editou decreto legislativo para sustar alguns artigos do decreto regulamentador. A contenda resumia-se ao que significava remuneração para fins de teto constitucional. Na visão do órgão legislativo, o Executivo tinha exagerado, de modo que prejudicou vários servidores, que viram suas remunerações diminuídas. Entendeu o Supremo que o art. 49, V, da Constituição Federal (que prevê a competência do Congresso Nacional para sustar atos exorbitantes do Executivo quando do seu exercício do poder regulamentar), abrange os decretos regulamentares dos demais executivos da federação, e, neste sentido, estariam os poderes legislativos da federação autorizados a sustar tais decretos, mediante decretos legislativos, quando ilegais os regulamentos. Assim, se o decreto legislativo sustasse mal o decreto, poderia haver controle de constitucionalidade concentrado (e, com mais razão, difuso no STF), visto que, aqui, haveria sempre ofensa direta à Constituição, conforme já explicitado. Muito embora esta opinião não seja generalizada, visto que o STF já julgou em contrário, em 1992, na alegação era de que 0 ato de sustação era um ato de efeitos concretos, e não normativo, motivo 
pelo qual fugiria à lógica do controle concentrado.

Como o STF prefere não enfrentar as questões de adequação entre decreto e lei, é necessário procurar algumas posições na jurisprudência do STJ.

O STJ mantém a tradição, ao afirmar que o decreto não pode criar novos direitos e obrigações. Neste sentido, o Recurso Especial № 751.398 - MG (2005/ 0081771-4), Relatora Ministra Denise Arruda. Nele se discute a possibilidade de 0 decreto criar tipos administrativos de sanções quando a lei atribui à Administração Pública o dever de fiscalizar. O STJ não permitiu tal interpretação ${ }^{43}$.

E seguem citações da doutrina já invocada neste trabalho.

O STJ teve de julgar, certa feita, sobre a possibilidade de o decreto estabelecer prazos que a lei não colocou. É que a lei 9.675, que trata da regularização da situação do estrangeiro no Brasil, não alocou prazo a esta regularização; o decreto (Decreto 2.771/98), contudo, estabeleceu um prazo decadencial. Neste julgamento reafirmou-se a idéia de que o regulamento deve ater-se a conteúdos procedimentais e formais, ou a esclarecer a vagueza da lei ${ }^{44}$ :

Desse modo, é flagrante a ilegalidade/ inconstitucionalidade do prazo de noventa dias fixado pelo art. $4^{\circ}$ do Decreto 2.771 98 , pois, nesse ponto, o regulamento não se restringiu a dispor sobre aspecto de ordem formal ou procedimental, tampouco esclarecer conceito vago ou decompor o conteúdo de preceito sintético; ao revés, criou prazo decadencial não previsto em lei, atingindo, diretamente, o direito material objeto da regulamentação ${ }^{45}$.

Importante notar que, aqui, utilizaram as palavras "ilegalidade/constitucionalidade", enquanto que, na ementa, apenas a ilegalidade foi mencionada. De fato, viu-se que há bons motivos para tamanha confusão.

Certa feita, o STJ considerou que os únicos "regulamentos" passíveis de serem controlados via Recurso Especial eram os que advinham em forma de decreto. Portarias e resoluções não poderiam ser questionados no Recurso Especial ${ }^{46}$.

O STJ discutiu, também, se o decreto poderia estabelecer "condições" para o aproveitamento de algum benefício. Ocorre que a legislação tributária estabelece que a lei regulamentará os limites de isenção das verbas rescisórias trabalhistas em face do Imposto de Renda. O Decreto regulamentador dispôs que tais limites serão fixados em norma coletiva, além da própria lei.

$O$ inciso XX do art. 39 do Decreto 3.000 / 99 excede os limites do poder regulamentar, na medida em que, nos termos do dispositivo legal regulamentado, 'ficam isentos do imposto de renda (...) a indenização e o aviso prévio pagos por despedida ou rescisão de contrato de trabalho, até o limite garantido por lei". Conforme foi dito antes, a isenção é sempre decorrente de lei e deve ser interpretada literalmente. Logo, as indenizações pagas por despedida ou rescisão de contrato de trabalho que excederem os limites garantidos por lei, independentemente de estarem previstas em acordo coletivo, não se enquadram entre os rendimentos isentos a que se refere 0 art. $6^{\circ}$ da Lei $7.713 / 88^{47}$.

Noutra ocasião, o Tribunal entendeu que, se a Lei estabelece parâmetros 
máximos e mínimos de multa tributária, poderá o decreto estabelecer gradações entre os parâmetros, visando respeitar a proporcionalidade ${ }^{48}$.

Os acórdãos em geral, incluindo os do TJRS, evitam, todavia, tocar nas questões de adequação, usualmente simplesmente aferindo se o decreto criou ou não novo direito, sem maiores divagações sobre como isto é descoberto. Pretendese, no capítulo a seguir, estabelecer algumas reflexões acerca da maneira pela qual a hermenêutica poderia tratar da matéria.

\section{CONCLUSÃO}

A conclusão de um trabalho que se pretende crítico, e, assim, científico, na especificidade da seara jurídica é uma seção sempre um tanto quanto desprestigiada. Isto ocorre devido ao fato de que no conhecimento jurídico não se asseverem fatos e os meios de reproduzi-los: trata-se, isto sim, de argumentações que tem de tem de abrir os interrogantes do leitor, de modo que as construções argumentativas provoquem, mesmo que minimamente, uma fusão de horizontes. Estas argumentações ocorrem no transcorrer do texto, de modo que à conclusão não sobra muita utilidade.

O desenvolvimento do trabalho alcançou as seguintes conclusões, aqui apresentadas de maneira bastante simples, e que visam meramente retomar o que já fora trabalhado:

1) o decreto, além de ser instituto tradicional no Direito brasileiro, encontra guarida no texto constitucional;

2) dentre os vários tipos de decreto, interessa a este trabalho o decreto regulamentar ou executivo, cuja função é regulamentar a lei;

3) regulamentar a lei tem sido entendido pela doutrina como uma atividade onde a preocupação é minudenciar os termos legais;

4) isto significa que não pode o decreto dispor de maneira "criativa", isto é, estipulando direitos e deveres, ou dirimindo dúvidas;

5) a jurisprudência, se bem que segue a doutrina em sua maior parte, pensa o decreto de maneira mais liberal ao Executivo, de modo que a atividade regulamentar pode suprir as "lacunas" deixadas pela lei;

6) é o peculiar processo que rege a união entre o algo-a-ser-compreendido e a tradição daquele que busca compreender, em um acontecer inarredável que reside nas entranhas do dia-a-dia da compreensão, que permite 0 acesso a qualquer conhecimento;

7) se fazer o decreto tem um pouco de razão prática, estariam abertas as portas da discricionariedade?;

8) a formação democrática da norma implica em abertura procedimental à esfera pública; todos os participantes devem ter oportunidade de canalizar suas 
considerações à esfera pública e esta aos canais institucionalizados;

9) do mesmo modo, o decreto guarda diferenças no que toca ao modo pelo qual ocorre a hermenêutica e como a racionalidade prática o percebe;

10) o poder administrativo se expressa, devido à sua função operativa, ao final da cadeia argumentativa, tenho um cunho pragmático, isto é, dos melhores meios para alcançar um determinado fim.

\section{THE "REGULATORY DECREE" IN BRAZILIAN LAW AND THEY MAINLY ISSUES: SMALL ANALYSIS ABOUT MATERIAL CASES.}

\section{ABSTRACT}

This work seeks the meaning of the juridical institute "regulatory decree". Along the many questions to be answered, the mains stream evolves the decree as some kind of law's application and its difficulties - the biggest of them the inexistence of first ordinary premise of interpretation: the "case" or "fact" existence. To understand these problems, the first step will be the analysis of the dogmatic approach. Them, some paradigmatic cases solved by jurisprudence.

Keywords: Decree. Jurisprudence. Law's Theory. Legal signs.

\section{NOTAS}

1 Professor do Programa de Pós-Graduação em Direito da Universidade de Santa Cruz do Sul, Mestrado e Doutorado. Doutor em Direito pela Universidade do Vale do Rio dos Sinos. Advogado.

2 Professora da Universidade de Santa Cruz do Sul. Mestre em direito. Especialista em Direito Público. Integrante do grupo de pesquisa "Jurisdição Constitucional Aberta"vinculado ao Cnpq. Advogada.

3 CRETELLA Júnior, José. Curso de Direito Administrativo. 16. ed. Forense: Rio de Janeiro, 1999. p.238

4 Utilizou-se a palavra "primária" nesta frase porque há outras funções para o decreto, emergentes de outras problemáticas, mas que utilizam o mesmo veículo normativo.

5 MELlO, Celso Antônio Bandeira de. Curso de Direito Administrativo. 12. ed. São Paulo: Malheiros, 2000. p.321.

6 MELLO, Celso Antônio Bandeira de. Curso de Direito Administrativo. 12. ed. São Paulo: Malheiros, 2000. p.296.

7 CANOTILHO, Joaquim José Gomes. Direito Constitucional e Teoria da Constituição. 4. ed. Coimbra: Almedina, 2000. p.716.

8 Isto é, a idéia de que os poderes públicos devem pautar por normas pré-estabelecidas, não necessariamente "Leis".

9 Tomados aqui no sentido de sucessão de atos.

10 MIRANDA, Francisco Cavalcanti Pontes de. Comentários à Constituição de 1946. VII. 2. ed. Max Limonad: São Paulo, 1953. p.411.

11 PIETRO, Maria Sylvia Zanella di. Direito Administrativo. 19. ed. São Paulo, Atlas, 2006.p.102.

12 CARRAZZA, Roque Antônio. O Regulamento no Direito Brasileiro. São Paulo: Revista dos Tribunais, 1981. p. 115: "A faculdade de regulamentar provém de um poder próprio da Administração Pública" 
CRETELLA Júnior, José. Curso de Direito Administrativo. 16. ed. Forense: Rio de Janeiro, 1999. p.239: 'Na hierarquia das normas, representam os regulamentos o grau mais alto na esfera administrativa, logo abaixo das normas legais, sendo a complementação destas. Pelo nosso sistema constitucional, são os regulamentos aprovados por decreto executivo e a sua amplitude só encontra limites nos textos legais regulamentados".

CARRAZZA, Roque Antônio. $O$ Regulamento no Direito Brasileiro. São Paulo: Revista dos Tribunais, 1981. p.8.

'Legislativa" aqui tomada não no sentido técnico-jurídico, mas sim no de oposição aquele de atos concretos.

MORAIS, Alexandre de. Direito Constitucional. 19. ed. São Paulo: Atlas, 2006. p.437: 'O exercício do poder regulamentar do Executivo situa-se dentro da principiologia constitucional da Separação de Poderes (CF, arts. $\left.2^{\circ}, 60, \S 4^{\circ}, \mathrm{III}\right)$, pois, salvo em situações de relevância ou urgência (medidas provisórias), o Presidente da República não pode estabelecer normas gerais criadoras de direitos ou obrigações, por ser funções do Poder Legislativo. Assim, o regulamento não poderá alterar disposição legal, tampouco criar obrigações diversas das previstas em disposição legislativa".

Em realidade, "regulamento" parece ser um predicado de algum veículo normativo, posto que regulamentos podem ser entificados por portarias, ou por atos de empresas públicas, etc., e não apenas por decretos. A dogmática ainda é muito confusa neste aspecto.

CARRAZZA, Roque Antônio. $O$ Regulamento no Direito Brasileiro. São Paulo: Revista dos Tribunais, 1981. p. 8. CARRAZZA, Roque Antônio. O Regulamento no Direito Brasileiro. São Paulo: Revista dos Tribunais, 1981. 14

21 MELlO, Celso Antônio Bandeira de. Curso de Direito Administrativo. 12. ed. São Paulo: Malheiros, 2000. p. 303.

Esta parece ser a posição mais comum. Ver, por exemplo, MORAIS, Alexandre de. Direito Constitucional. 19. ed. São Paulo: Atlas, 2006. p.437: 'Essa vedação não significa que o regulamento deva reproduzir literalmente o texto da lei, pois seria de flagrante inutilidade. $O$ poder regulamentar somente será exercido quando alguns aspectos da aplicabilidade da lei são conferidos ao Poder Executivo, que deverá evidenciar e explicitar todas as previsões legais, decidindo a melhor forma de executá-la e, eventualmente, inclusive, suprindo suas lacunas de ordem prática ou técnica".

MELLO, Celso Antônio Bandeira de. Curso de Direito Administrativo. 12. ed. São Paulo: Malheiros, 2000. p.296. p. 305.

MELLO, Celso Antônio Bandeira de. Curso de Direito Administrativo. 12. ed. São Paulo: Malheiros, 2000. p.305. Tribunais, 1981, p. 138 GRAU, Eros Roberto. O Direito Posto e o Direito Pressuposto. 3. ed. São Paulo: Malheiros, 2000. p.183.

27 MIRANDA, Francisco Cavalcanti Pontes de. Comentários à Constituição de 1946. VI. 2. ed. Max Limonad: São Paulo, 1953. p.411. Aliás, uns dos autores que mais profundamente comentou o tema.

MELLO, Celso Antônio Bandeira de. Curso de Direito Administrativo. 12. ed. São Paulo: Malheiros, 2000. p.321: "São visíveis, pois, a natural inadequação e os imensos riscos que adviriam para os objetivos essenciais do Estado de Direito - sobreposse, repita-se, em um país ainda pouco afeito a costumes políticos mais evoluídos - de um poder regulamentar que pudesse definir, por força própria, direitos ou obrigações de fazer ou não fazer imponíveis aos administrados". MIRANDA, Francisco Cavalcanti Pontes de. Comentários à Constituição de 1946. VI. 2. ed. Max Limonad: São Paulo, 1953. p.412.

MIRANDA, Francisco Cavalcanti Pontes de. Comentários à Constituição de 1946. VI. 2. ed. Max Limonad: São Paulo, 1953. p.193. MIRANDA, Francisco Cavalcanti Pontes de. Comentários à Constituição de 1946. VI. 2. ed. Max Limonad: São Paulo, 1953. p.412.

33 MIRANDA, Francisco Cavalcanti Pontes de. Comentários à Constituição de 1946. VI. 2. ed. Max Limonad: São Paulo, 1953. p.413.

34 Muito embora, neste caso, seria possível recorrer a outras categorias, como a de ônus e faculdade. Isto não evitaria o problema, de todo modo. 
Que é outro processo delicado de compreensão. MIRANDA, Francisco Cavalcanti Pontes de. Comentários à Constituição de 1946. VI. 2. ed. Max Limonad: São Paulo, 1953. p. 411.

MIRANDA, Francisco Cavalcanti Pontes de. Comentários à Constituição de 1946. VI. 2. ed. Max Limonad: São Paulo, 1953. p. 412.

CARRAZZA, Roque Antônio. O Regulamento no Direito Brasileiro. São Paulo: Revista dos Tribunais, 1981. p.165.

MIRANDA, Francisco Cavalcanti Pontes de. Comentários à Constituição de 1946. VI. 2. ed. Max Limonad: São Paulo, 1953. p. 411.

MIRANDA, Francisco Cavalcanti Pontes de. Comentários à Constituição de 1946. VI. 2. ed. Max Limonad: São Paulo, 1953. p.411.

BRASIL. Supremo Tribunal Federal. RE 346.084-6 PR. Rel. Min. IImar Galvão. 9.11. 2005.

BRASIL. Superior Tribunal de Justiça. Recurso Especial N 415.269 - RS (2002/ 0017892-4). Relatora Ministra Eliana Calmon. Julgado em 14/04/2002.

Com efeito, da análise das Leis 8.987/ 95 (art. 29, I e II) e 10.233/ 2001 (art. 78-A, II) e do Decreto 2.521/ 98 (art. 83), conclui-se pela legalidade da multa aplicada em razão da prática de transporte rodoviário interestadual de passageiros sem autorização. No entanto, a penalidade de apreensão do veículo e sua restituição condicionada ao pagamento da multa e demais encargos (Decreto 2.521 98, art. 85) não têm previsão legal, ou seja, foram instituídas, de maneira autônoma, exclusivamente no ato regulamentar expedido pelo Chefe do Poder Executivo Federal. A Constituição Federal, na seção que trata das atribuições do Presidente da República, prevê que é de sua competência privativa "sancionar, promulgar e fazer publicar as leis, bem como expedir decretos e regulamentos para sua fiel execuçä" (art. 84, IV). Para o professor Hely Lopes Meirelles, o poder regulamentar "é a faculdade de que dispóem os Chefes de Executivo (Presidente da República, Governadores e Prefeitos) de explicar a lei para sua correta execução, ou de expedir decretos autônomos sobre matéria de sua competência ainda não disciplinada em lei. É um poder inerente e privativo do Chefe do Executivo (CF, art 84, IV), e, por isso, indelegável a qualquer subordinado" (Direito Administrativo Brasileiro, $30^{\mathrm{a}}$ ed., São Paulo: Malheiros, 2005, p. 127). Esse entendimento, porém, é minoritário na doutrina e diverge da posição dominante, que não admite a possibilidade de o Poder Executivo editar os denominados regulamentos autônomos ou independentes - atos destinados a prover situações nãopredefinidas na lei -, mas, tão-somente, os regulamentos de execução, destinados a explicitar o modo de execução da lei regulamentada.

Isto não pode ser levado muito a sério, pois o próprio STJ considerou o SAT possível.

BRASIL. Superior Tribunal de Justiça. Recurso Especial No 526.015 - Santa Catarina (2003/ 0047965-8), Relatora Ministra Denise Arruda. Julgado em 07/ 02/ 2006.

BRASIL. Superior Tribunal de Justiça. Recurso Especial No 947136 - São Paulo (2007/00960438), Relatora Ministro Castro Meira. Julgado em 18/08/ 2007.

BRASIL. Superior Tribunal de Justiça. EDcl no REsp 890816- São Paulo (2006/ 0213946-1), Relatora Ministra Denise Arruda. Julgado em 05/ 06/ 2007.

BRASIL. Superior Tribunal de Justiça REsp 769404 - Santa Catarina (2005/ 0120468-1), Relatora Ministra Luiz Fux. Julgado em 15/ 03/ 2007.

\section{REFERÊNCIAS}

BRASIL. Supremo Tribunal Federal. RE 346.084-6 PR. Rel. Min. IImar Galvão. 9.11. 2005.

BRASIL. Superior Tribunal de Justiça. Recurso Especial No 415.269 - RS (2002/ 0017892-4). Relatora Ministra Eliana Calmon. Julgado em 14/04/2002.

BRASIL. Superior Tribunal de Justiça. Recurso Especial № 526.015 - Santa Cararina (2003/ 0047965-8), Relatora Ministra Denise Arruda. Julgado em 07/ $02 / 2006$. 
(2007/0096043-8), Relatora Ministro Castro Meira. Julgado em 18/ 08/ 2007.

BRASIL. Superior Tribunal de Justiça. EDcl no REsp 890816- São Paulo (2006/ 0213946-1), Relatora Ministra Denise Arruda. Julgado em 05/ 06/ 2007.

BRASIL. Superior Tribunal de Justiça REsp 769404 - Santa Catarina (2005/ 0120468-1), Relatora Ministra Luiz Fux. Julgado em 15/ 03/ 2007.

CANOTILHO, Joaquim José Gomes. Direito Constitucional e Teoria da Constituição. 4. ed. Coimbra: Almedina, 2000.

CRETELLA Júnior, José. Curso de Direito Administrativo. 16. ed. Forense: Rio de Janeiro, 1999.

GRAU, Eros Roberto. O Direito Posto e o Direito Pressuposto. 3. ed. São Paulo: Malheiros, 2000.

MELLO, Celso Antônio Bandeira de. Curso de Direito Administrativo. 12. ed. São Paulo: Malheiros, 2000.

MIRANDA, Francisco Cavalcanti Pontes de. Comentários à Constituição de 1946. VII. $2^{\mathrm{a}}$ ed. Max Limonad: São Paulo, 1953.

MORAIS, Alexandre de. Direito Constitucional. 19. ed. São Paulo: Atlas, 2006.

PIETRO, Maria Sylvia Zanella di. Direito Administrativo. 19. ed. São Paulo, Atlas, 2006.

Recebido para publicação 08/12/2009

Aceito para publicação 28/12/2009 